\title{
Saccardoëlla kanderana (Ascomycota), a species and genus new to Finland
}

\author{
GEIR MATHIASSEN, ALFRED GRANMO and TEPPO RÄMÄ
}

\begin{abstract}
MATHIASSEN, G., GRANMO, A. \& RÄMÄ, T. 2013: Saccardoëlla kanderana (Ascomycota), a species and genus new to Finland - Karstenia 53: 00-00. HELSINKI. ISSN 0453-3402.

Key words: Ascomycota, ecology, Finland, genera incertae sedis, Saccardoëlla kanderana, Sordariomycetes, taxonomy

Geir Mathiassen \& Alfred Granmo \& Teppo Rämä, Department of Natural Sciences, Tromsø University Museum, University of Tromsø, NO-9037 Tromsø, Norway; e-mails: geir.mathiassen@uit.no \& alfred.granmo@uit.no \& teppo.rama@uit.no
\end{abstract}

This is the first report of the genus Saccardoëlla and species Saccardoëlla kanderana from Finland. The pyrenomycetous species $S$. kanderana was found on two Salix species in three localities in the northwest of the country, in the biogeographical province of Enontekiön Lappi in 1996 and 2002. Three Norwegian finds of the species are also reported, one of them representing the hitherto northernmost locality in the world. An overview of the genus is given and the host preference and distribution of the species are briefly discussed.

\section{Introduction}

During fieldwork in the northern part of Finland in 1996 and 2002, the senior author (GM) collected a few specimens of Saccardoëlla kanderana Math. The species was found on Salix in three localities in the biogeographical province Enontekiön Lappi. These are the first records of the genus Saccardoëlla Speg. and the species S. kanderana from Finland. The first known records of Saccardoëlla kanderana from Scandinavia were published by Mathiassen (1989) as Saccardoëlla transylvanica (Rehm) Berl., occurring on Salix in Norway. A closer examination of the type mate- rial of S. transylvanica (on Syringa), S. berberidis Eliasson (on Berberis) and S. canadensis Ellis \& Everh. (on Crataegus) revealed that the material on Salix actually represented a separate species. The species was therefore described as new by Mathiassen (1993). In Norway Saccardoëlla kanderana is known from several localities in Troms and Nordland (Mathiassen 1989, 1993), and from one locality in Finnmark (Granmo 2008). The first records from Sweden were reported by Mathiassen \& Økland (2007).

\section{Characteristics of Saccardoëlla kanderana}

The stroma surrounding the ascomata is clypeoid, and only scantily developed. Ascomata are 540-900 $\mu \mathrm{m}$ in diam., globose, usually scattered and almost completely immersed, only with the \pm conical, black papillae visible (Fig.1). Ostiolum cylindrical, periphysate. Asci 260-348 × 10.4-14 $\mu \mathrm{m}$, cylindrical, short-stiped, rather thick-walled, 8-spored. Interascal hyphae 2.5-4 $\mu \mathrm{m}$ wide at base, but gradually tapering towards apex, numerous, long, septate, and somewhat branched above the asci. Ascospores (35-) $40-60 \times 7.5-10 \mu \mathrm{m}$, ellipsoid to broadly fusiform, slightly curved, 11-18-septate, constricted at the middle septum, hyaline and obliquely uniseriate (Fig. 2).

Saccardoëlla kanderana is macroscopically often confusingly similar to Amphisphaerella erikssonii Math. and 
Barrmaelia oxyacanthae (Mont.) Rappaz, which are easily distinguished microscopically by their one-celled, brown ascospores. The species is, however, close to $S$. transylvanica, but differs in several characters, among others by having truly septate ascospores, which also are constricted at the central septum. For more comprehensive descriptions and illustrations see Mathiassen (1989, 1993).

\section{Concept and history of the genus Saccardoëlla}

The genus Saccardoëlla was described to accommodate the Italian S. montellica Speg., found in the cortex of old Quercus in northern Italy, January 1879 (Spegazzini 1879). Characteristics include ascomata about $1 \mathrm{~mm}$ in dia, which are immersed to erumpent and stoutly papillate ostioles. The asci are long cylindrical, unitunicate, with an apical ring and uniseriate hyaline ascospores having several transverse septa and sheaths or appendages. The genus was reviewed by Petrak (1962), Hyde (1992) and Barr (1994). After these reviews, species with divergent spore characteristics have been included in the genus. Thus, Tsui et al. (1998) provided a key to the published species of Saccardoëlla, which also included species with ascospores lacking sheaths or polar appendages, and one species with only 3 -septate ascospores. This key was later updated by Cai et al. (2002) with the addition of five species. One of these, S. graeweana (Blomb.) M.E. Barr, L. Holm \& $\mathrm{K}$. Holm, has asci with overlapping biseriate ascospores (Barr et al. 1998). The generic concept of Saccardoëlla is currently indistinct. The genus should be redefined and the genus description amended to include also species with 3 -septate and biseriate ascospores, if molecular phylogenies support their placement in Saccardoëlla.

The systematic position of the genus Saccardoëlla has been uncertain for a long time, and has been assessed differently by various authors, e.g. Saccardo (1883), Ellis \& Everhart (1892), Berlese (1894), Müller (1959), Petrak (1962), Eriksson (1984, 1999), and Barr (1990, 1994). In a phylogenetic analysis of the tropical/subtropical $S$. rhizophorae K.D. Hyde by Suetrong et al. (2009), the species did not group within any known family or order. According to Cai et al. (2002) the genus is morphologically heterogeneous, including species that are clearly not related. The ascus type has been debated, but remains unresolved. Mathiassen (1989) described the interascal hyphae as pseudoparaphyses, and the asci as bitunicate in his specimens from Norway, but was later (Mathiassen 1993) inclined to agree with Eriksson \& Hawksworth $(1990,1991)$ that the asci seemed to be unitunicate. However, Li \& Zhuang (2008) described their taxon S. psidiicola W.Y. Zhuang, W.Y. Li \& K.D. Hyde as bitunicate. The concept and position of the genus is still uncertain, and it is at present included among the Sordariomycetes, genera incertae sedis (Lumbsch \& Huhndorf 2010).

The genus has a wide geographical distribution, with almost 20 species recorded from several parts of the world, including temperate and subtropical zones in both the northern and southern hemisphere (Cai et al. 2002, Li \& Zhuang 2008). Species of the genus occur on wood in

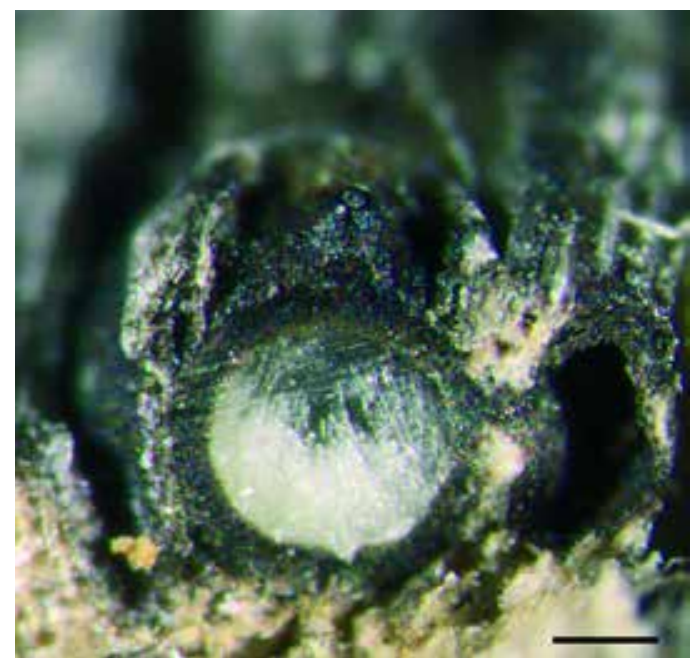

Fig. 1. Saccardoëlla kanderana, a vertically cut perithecium (Mathiassen 11615). Scale $\approx 200 \mu \mathrm{m}$. Photo: G. Mathiassen (C)

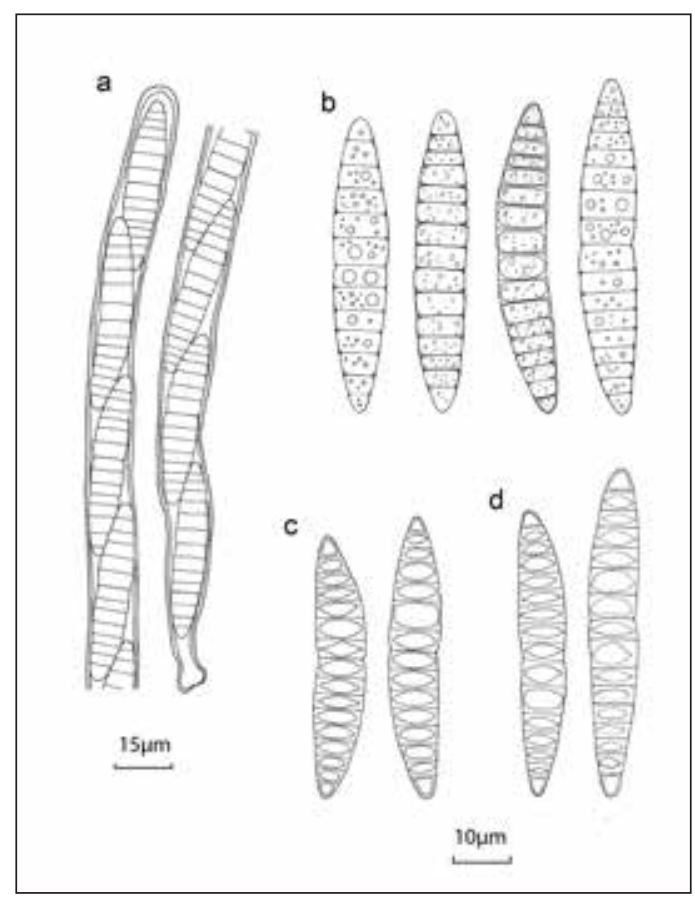

Fig. 2. Saccardoëlla kanderana, type specimen (Mathiassen 1974A). a = ascus with eight ascospores, $\mathrm{b}=$ ascospores mounted in water, $\mathrm{c}=$ ascospores stained in lactophenol cotton blue, $\mathrm{d}=$ ascospores mounted in $\mathrm{KOH}$ (2\%). Drawing: Mathiassen. 


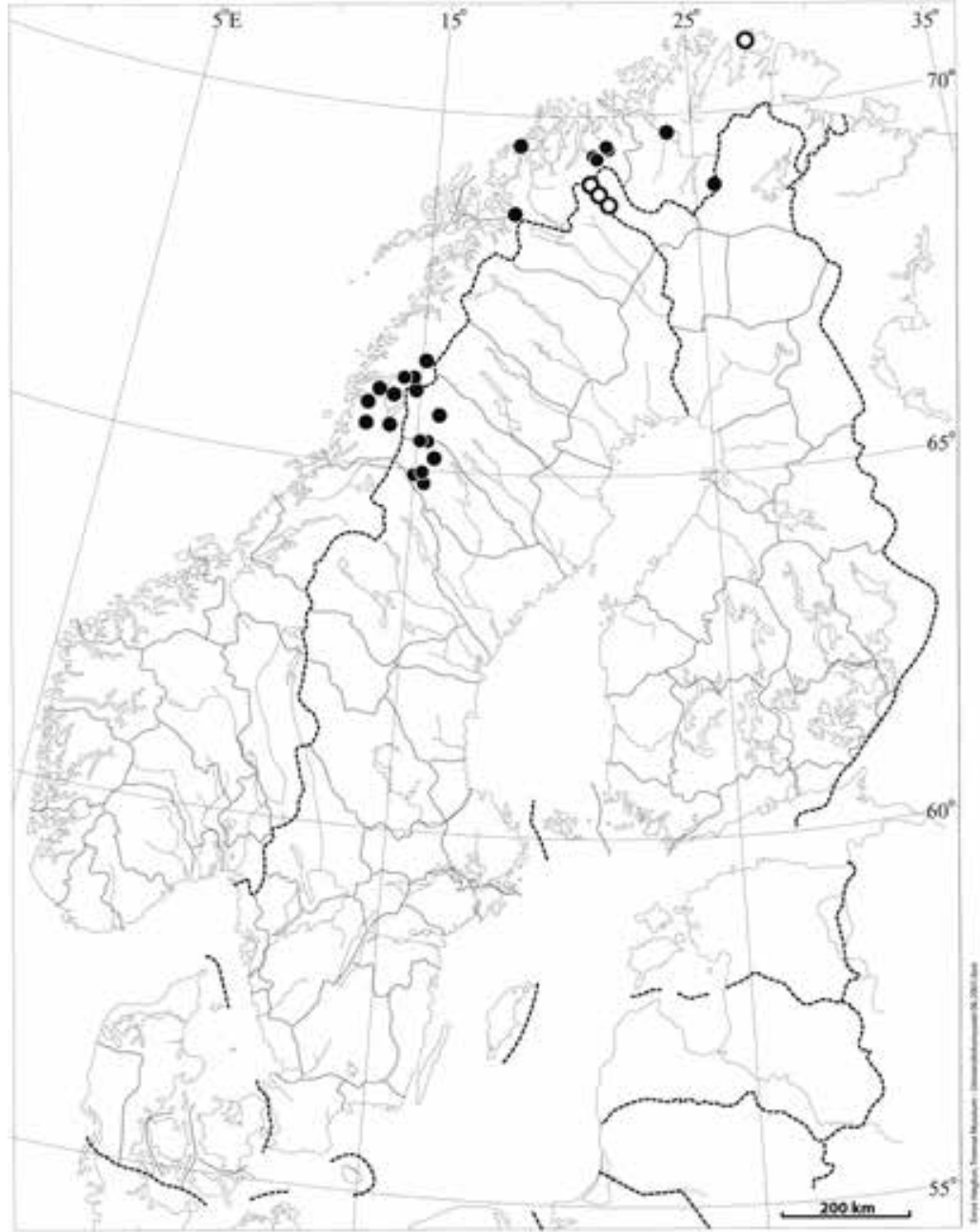

Fig. 3. Distribution of Saccardoëlla kanderana in Fennoscandia. $=$ Localities in Finland, and the world's northernmost locality in Norway. Map: E. Høgtun (C), Tromsø University Museum, 2012. terrestrial, aquatic and marine habitats as well. Mathiassen (1993) pointed out that the three northern hemisphere species, Saccardoëlla berberidis (Sweden), S. canadensis (Canada) and S. transylvanica (Central Europe) probably represented only one taxon, and stated that this group of species should be thoroughly reexamined. If the first two species actually were inseparable from $S$. transylvanica, the latter name would be the valid one, meaning that $S$. transylvanica would be the most widespread, although not a common species.

\section{Results and discussion}

The three Finnish localities of Saccardoëlla kanderana are all in the northwesternmost part of the country, in north boreal and low alpine zones (Fig. 3). In Scandinavia, the main distribution of
S. kanderana is also in the north boreal and low alpine areas. As it is rather frequent in the central inland parts of Norway and Sweden (Mathiassen 1993, Mathiassen \& Økland 2007) and in Troms, North Norway, it probably occurs all along the Scandinavian mountain range. Saccardoëlla kanderana is also found in the Swiss Alps and has the same disjunct distributional pattern in Europe as Glyphium grisonense Math. (Mathiassen 1993, Mathiassen \& Økland 2007). Vasilyeva's Russian records from Eastern Siberia, published as $S$. transylvanica, are considered by us to represent $S$. kanderana, based on her own description (Vasilyeva 1998).

The northernmost locality of the species in Fennoscandia is in Norway, in Oksevågdalen 
Nature Reserve, Finnmark ( $70^{\circ} 57^{\prime} \mathrm{N}, 27^{\circ} 30^{\prime} \mathrm{E}$; Fig. 3), and was found in 2008 (Granmo 2008). This was the first and only record from that county until the species was collected in two new Finnmark localities in the municipalities of Alta and Karasjok in 2010.

In central and northern Scandinavia, Saccardoëlla kanderana is most frequent on Salix glauca agg., S. lapponum and on S. myrsinifolia agg. The preferred hosts can to some extent be correlated with its distribution pattern, as it is most frequent in north boreal and low alpine areas. It is also found on S. arbuscula, S. caprea ssp. sphacelata, S. hastata ssp. hastata, S. lanata ssp. lanata and S. pentandra (Mathiassen 1989, 1993, Mathiassen \& Økland 2007). In northern Finland, $S$. kanderana was found on S. glauca ssp. glauca and on S. phylicifolia. The species is indeed closely associated with Salix spp., but in 2010 it was found on Betula in Jotka Forest Reserve, Alta. Saccardoëlla kanderana is found on wood and bark, but has some preference for naked wood. It is most frequently found on dead, old branches, and often close to the ground.

Finnish material of Saccardoëlla kanderana (Finnish grids given in Finnish uniform grid $27^{\circ} \mathrm{E}$ ): Enontekiön Lappi. Enontekiö, Kilpisjärvi, SW slope of Saana, 7675:3253, on Salix glauca ssp. glauca, 30.VII.1996 Mathiassen $10374(\mathrm{H})$; SE of lake Kilpisjärvi, at Muotkatakka, 7660:3258, on S. glauca ssp. glauca, 9.IX.2002 Mathiassen 11615 (OULU); same site and host, in coll. Mathiassen 11618, 11622, 11623 (TROM); SE of Saarikoski, near Lammasoaivi, 7642-3:3269, on S. phylicifolia, 31.VII.1996 Mathiassen 10444A (TUR).

Acknowledgements: We thank Ernst Høgtun for drawing the map and Rob Barrett and Ernest Emmett for improving the English. Thanks also to herbarium authorities at the Finnish herbaria in H, JOE, JYV, KUO, OULU and TUR for checking possible collections of Saccardoëlla. The investigation has been financially supported by the University of Tromsø, the County Governor of Finnmark, and Artsdatabanken (The Norwegian Biodiversity Information Centre).

\section{References}

Barr, M.E. 1990: Prodromus to nonlichenized, pyrenomycetous members of class Hymenoascomycetes. Mycotaxon 39: 43-184.

Barr, M.E. 1994: Notes on the Amphisphaeriaceae and related families. - Mycotaxon 51: 191-224.

Barr, M.E., Holm, L. \& Holm, K. 1998: Reappraisal of Sphaeria ordinata sensu Broome. - Mycotaxon 69: 31-34.
Berlese, A.N. 1894: Icones Fungorum 1. - Bibliotheca Mycologica 16A: 1-243.

Cai, L., Lumyong, P., Zhang, K. \& Hyde, K.D. 2002: New species of Annulatascus and Saccardoëlla from the Philippines. - Mycotaxon 84: 255-263.

Ellis, J.B. \& Everhart, B.M. 1892: The North American Pyrenomycetes. - 793 pp. Published by the authors. Newfield, New Jersey.

Eriksson, O. 1984: Outline of the Ascomycetes - 1984. Systema Ascomycetum 3: 1-72.

Eriksson, O.E. (ed.) 1999: Outline of Ascomycota - 1999. - Myconet 3: 1-88.

Eriksson, O.E. \& Hawksworth, D.L. 1990: Outline of the Ascomycetes - 1990. - Systema Ascomycetum 9: 39-271.

Eriksson, O.E. \& Hawksworth, D.L. 1991: Notes on ascomycete systematics. Nos 1128-1251. - Systema Ascomycetum 10: 27-67.

Granmo, A, 2008: Sopp i Oksevågdalen naturreservat. Naturkonsulenten, rapp. 2008-2. Fylkesmannen i Finnmark. Miljøvernavdelingen, rapport nr. 2-2009. http:// fylkesmannen.no/liste.aspx?m=1935\&amid=1001566

Hyde, K.D. 1992: The genus Saccardoëlla from intertidal mangrove wood. - Mycologia 84: 803-810.

Li, W.Y. \& Zhuang, W.Y. 2008: New species and new Chinese records of Dothideomycetes. - Mycotaxon 106: 413-418.

Lumbsch, H.T. \& Huhndorf, S.H. 2010: Myconet Volume 14. - Fieldiana, Life and Earth Sciences 1: 1-64.

Mathiassen, G, 1989: Some corticolous and lignicolous Pyrenomycetes s. lat. (Ascomycetes) on Salix in Troms, N Norway. - Sommerfeltia 9: 1-100.

Mathiassen, G, 1993: Corticolous and lignicolous Pyrenomycetes s. lat. (Ascomycetes) on Salix along a midScandinavian transect. - Sommerfeltia 20: 1-180.

Mathiassen, G. \& Økland, R.H. 2007: Relative importance of host tree species and environmental gradients for epiphytic species composition, exemplified by pyrenomycetes s. lat. (Ascomycota) on Salix in central north Scandinavia. - Ecography 30: 251-263.

Müller, E. 1959 [1958]: Pilze aus dem Himalaya II. - Sydowia 12: 160-184.

Petrak, F. 1962: Über die Gattung Saccardoëlla Speg. Sydowia 15: 233-236.

Saccardo, P.A. 1883: Sylloge Fungorum. Vol. 2. - Patavia.

Spegazzini, C. 1879: Nova addenda ad mycologiam venetam. - Michelia 1: 453-487.

Suetrong, S., Schoch, C.L., Spatafora, J.W., Kohlmeyer, J., Volkmann-Kohlmeyer, B., Sakayaroj, J., Phongpaichit, S., Tanaka, K., Hirayama, K. \& Jones, E.B.G. 2009: Molecular systematics of the marine Dothideomycetes. - Studies in Mycology 64: 155-173.

Tsui, K.M., Hyde, K.D., Hodgkiss, I.J. \& Goh, T.K. 1998: A new freshwater species of Saccardoëlla from Hong Kong and South Africa. - Mycologia 90: 701-704.

Vasilyeva, L.N. 1998: Plantae non vasculares, Fungi et Bryopsidae orientis extremi Rossica. Fungi. Vol. 4. Pyrenomycetidae et Loculoascomycetidae. - St Petersburg: Nauka. 